\title{
The dual role of asporin in breast cancer progression
}

Research Paper

\author{
Dana Simkova ${ }^{1}$, Gvantsa Kharaishvili' ${ }^{1}$, Gabriela Korinkova ${ }^{1}$, Tomas Ozdian ${ }^{2}$, Tereza \\ Suchánková-Kleplová ${ }^{3}$, Tomas Soukup ${ }^{3}$, Michal Krupka ${ }^{4}$, Adela Galandakova ${ }^{5}$, \\ Petr Dzubak' ${ }^{\text {, Maria Janikova }}{ }^{\text {, Jiri Navratil }}{ }^{\text {, Zuzana Kahounova }}{ }^{7,8}$, Karel Soucek ${ }^{7,8,9}$, \\ Jan Bouchal ${ }^{1}$

\footnotetext{
${ }^{1}$ Department of Clinical and Molecular Pathology, Institute of Molecular and Translational Medicine, Faculty of Medicine and Dentistry, Palacky University, Olomouc, Czech Republic

${ }^{2}$ Laboratory of Experimental Medicine, Institute of Molecular and Translational Medicine, Faculty of Medicine and Dentistry, Palacky University, Olomouc, Czech Republic

${ }^{3}$ Department of Histology and Embryology, Faculty of Medicine in Hradec Kralove, Charles University, Hradec Kralove, Czech Republic

${ }^{4}$ Department of Immunology, Faculty of Medicine and Dentistry, Palacky University, Olomouc, Czech Republic

${ }^{5}$ Department of Medical Chemistry and Biochemistry, Institute of Molecular and Translational Medicine, Faculty of Medicine and Dentistry, Palacky University, Olomouc, Czech Republic

${ }^{6}$ Department of Comprehensive Cancer Care, Masaryk Memorial Cancer Institute, Brno, Czech Republic

${ }^{7}$ Department of Cytokinetics, Institute of Biophysics, Academy of Sciences of the Czech Republic, v.v.i., Brno, Czech Republic

${ }^{8}$ Center of Biomolecular and Cellular Engineering, International Clinical Research Center, St. Anne's University Hospital Brno, Brno, Czech Republic

${ }^{9}$ Department of Experimental Biology, Faculty of Science, Masaryk University, Brno, Czech Republic
}

Correspondence to: Jan Bouchal, email: jan.bouchal@upol.cz

Keywords: asporin, 3D cultivation, stiffness, grade, breast cancer

Received: October 14, $2015 \quad$ Accepted: June 29, 2016

Published: July 7, 2016

\section{ABSTRACT}

Asporin has been reported as a tumor suppressor in breast cancer, while asporinactivated invasion has been described in gastric cancer. According to our in silico search, high asporin expresion associates with significantly better relapse free survival (RFS) in patients with low-grade tumors but RFS is significantly worse in patients with grade 3 tumors. In line with other studies, we have confirmed asporin expression by RNA scope in situ hybridization in cancer associated fibroblasts. We have also found asporin expression in the Hs578T breast cancer cell line which we confirmed by quantitative RT-PCR and western blotting. From multiple testing, we found that asporin can be downregulated by bone morphogenetic protein 4 while upregulation may be facilited by serum-free cultivation or by three dimensional growth in stiff Alvetex scaffold. Downregulation by shRNA inhibited invasion of Hs578T as well as of CAFs and T47D cells. Invasion of asporin-negative MDA-MB-231 and BT549 breast cancer cells through collagen type I was enhanced by recombinant asporin. Besides other investigations, large scale analysis of aspartic acid repeat polymorphism will be needed for clarification of the asporin dual role in progression of breast cancer.

\section{INTRODUCTION}

Tumor progression is partly a result of evolving crosstalk between different cell types within the tumor and its surrounding supportive tissue/tumor stroma [1]. The extracellular matrix (ECM) is a dynamic structure providing constructional support, organisation and orientation into tissues [2] as well as supplying crucial elements for cell survival i.e. growth factors, inflammatory molecules and immune soluble mediators [3]. ECM consists of a plethora of proteins of varying structure and function [4]. Inter alia, the small leucine rich proteoglycan family (SLRPs) constitutes an important group of ECM proteins, widely found in most extracellular matrices [5].

Asporin was identified by three research groups in $2001[6,7,8]$. The aspartic acid rich $\mathrm{N}$-terminal region and 
central part of the asporin molecule bind type II collagen [9] while collagen $\mathrm{I}$ is bound by the central region. Asporin inhibits collagen fibrilogenesis and competes with decorin in binding the same sites. For this reason, this competition may have a role in regulating the development of ECM. The asporin N-terminal polyaspartate domain also binds calcium, and works in concert with other domains in order to initiate the mineralization of collagen [10]. Asporin plays an important role in normal development, in particular of cartilage, bone and teeth, while its genetic polymorphisms have been associated with various bone and joint diseases, including osteoarthritis, rheumatoid arthritis and lumbar disc disease [11].

We identified asporin by microdissection and expression profiling as a novel breast cancer related protein [12]. It was upregulated in invasive carcinomas, in particular lobular ones, together with other extracellular matrix proteins such as periostin or versican $[13,14]$. Asporin can also be found in gene lists from other expression microarray analyses both in breast and other cancer types [15-19]. Association of asporin with different types of cancer has also been confirmed by other methods such as tag profiling and mass spectrometry [20-23]. Important findings have been recently reported by Satoyoshi et al. [24] who found strong asporin expression in cancer associated fibroblasts and its importance in coordinated invasion of gastric cancer. On the other hand, Maris et al. [25] have described the tumor suppressive potential of asporin in breast cancer. With respect to these contradictory results, the role of asporin in cancer progression and the tumor microenvironment deserves further investigation.

\section{RESULTS}

\section{Asporin associates with better prognosis in low-grade tumors but not in high-grade breast cancer}

To acquire novel clues for the role of asporin in breast cancer we performed data mining using the Kaplan-Meier Plotter database comprising 4142 breast cancer patients. Detailed results on relapse free survival (RFS), overall survival and distant metastases free survival are summarized in Table 1 and Supplementary Table 1A. Although high asporin expression may serve as a good prognostic marker for tumor grades 1 and 2, the opposite can be observed in high-grade breast cancer (Figure 1A). High asporin expression is associated with significantly worse RFS both in estrogen receptor positive and negative grade 3 tumors, in particular with metastasis to lymph nodes (Figure 1B, Table 1). Asporin predicts good response to endocrine therapy in estrogen receptor positive breast cancer, in particular the luminal A molecular subtype. However, it is associated with worse RFS in the chemotherapy treated basal subtype or in the untreated luminal B subtype (Supplementary Table S1A).

Analysis of other cancer types showed significantly worse overall survival of ovarian and gastric cancer with high asporin expression. On the other hand, lung adenocarcinoma with high asporin expression had better outcome than patients with low asporin expression (Supplementary Table S1B).

\section{Identification of asporin positive cells in-vitro and antibody validation}

We have searched public repositories (Gene Expression Omnibus and Array Express) and found Hs578T as the only breast cancer cell line with asporin expression (Supplementary Figure S1A), which we confirmed by qRT-PCR (see below). Western blot results with several antibodies were not clear in relation to mRNA expression of positive gingival fibroblasts and negative breast cancer cell lines BT-549 and MDA-MB-231 (Supplementary Figure S2, Supplementary Table S2). Given the urgent need for a reliable antibody for subsequent experiments we saught another positive control. Asporin plays an important role in collagen mineralisation [10] and it has recently been found to be strongly upregulated during odontogenic differentiation of human dental pulp stem cells (hDPSC) [26]. We reproduced this finding (three independent samples with mean $\Delta \Delta \mathrm{Ct}$ 4.93 which corresponds to approximately 30 fold mRNA upregulation) and western blot results were in concordance with the mRNA levels (Figure 2, Supplementary Figure S2). Presence of asporin in the indicated double-band was further confirmed by mass spectrometry (Supplementary Figure S3, Supplementary Table S3).

\section{Asporin is regulated by $\mathrm{BMP} 4$, serum-starvation and $3 D$ cultivation in $\mathrm{Hs578T}$ cells}

We have tested multiple treatments which could modify expression of asporin in Hs578T. Expression of asporin is increased by TGF-beta in chondrocytes [27, 28], however, we observed no consistent upregulation of asporin after TGF-beta (Figure 3A, 1.3 mean fold upregulation). Other members of the TGF-beta family, BMP2 and 4, have been reported to increase asporin levels in periodontal ligament cells [29]. In breast cancer Hs578T cells, BMP4 slightly downregulated asporin and phosphorylation of focal adhesion kinase (FAK) at tyrosine 397 (2.4 and 2.1 mean fold downregulation, respectively), while $\mathrm{BMP} 2$ did not cause any consistent changes (Figure 3A, 1.2 mean fold downregulation). BMP4 also downregulated the asporin mRNA level (three independent samples with mean $\Delta \Delta \mathrm{Ct} 3.77$ which corresponds to approximately 14 fold mRNA downregulation).

Interestingly, asporin expression was markedly enhanced in serum free medium in comparison to a medium containing 10\% FBS (Figure 3A and 3D, 
Table 1: Prognostic value of high asporin expression in different breast cancer categories

\begin{tabular}{|c|c|c|c|c|c|c|c|c|c|c|c|c|}
\hline subtype* & status $* *$ & $\begin{array}{c}\text { prognostic } \\
\text { value }^{* * *}\end{array}$ & RFS & patients & status & $\begin{array}{l}\text { prognostic } \\
\text { value }\end{array}$ & OS & patients & status & $\begin{array}{l}\text { prognostic } \\
\text { value }\end{array}$ & DMFS & patients \\
\hline \multirow[t]{22}{*}{ any } & any & & 0.43 & 3554 & any & $\uparrow \uparrow$ & 0.046 & 1117 & any & & 0.42 & 1609 \\
\hline & $\mathrm{ER}+$ & $\uparrow$ & 0.067 & 1802 & ER+ & $\uparrow \uparrow \uparrow$ & 0.0012 & 377 & ER+ & $\uparrow \uparrow \uparrow$ & 0.0014 & 577 \\
\hline & ER- & $\downarrow \downarrow$ & 0.041 & 671 & ER- & & 0.16 & 142 & ER- & & 0.57 & 170 \\
\hline & Her2+ & $\downarrow$ & 0.081 & 168 & Her2+ & & n.d. & 28 & Her2+ & & 0.5 & 111 \\
\hline & Her2- & $\uparrow \uparrow$ & 0.048 & 756 & Her2- & & 0.25 & 62 & Her2- & & 0.18 & 82 \\
\hline & $\mathrm{LN}+$ & & 0.14 & 945 & $\mathrm{LN}+$ & & 0.33 & 197 & $\mathrm{LN}+$ & & 0.96 & 337 \\
\hline & LN- & & 0.61 & 1813 & LN- & $\uparrow \uparrow$ & 0.034 & 425 & LN- & $\uparrow \uparrow$ & 0.035 & 896 \\
\hline & G1 & $\uparrow \uparrow \uparrow$ & 0.0013 & 308 & G1 & & 0.13 & 135 & G1 & & 0.48 & 172 \\
\hline & G2 & $\uparrow \uparrow \uparrow$ & 0.0039 & 724 & G2 & $\uparrow \uparrow \uparrow$ & 0.00053 & 287 & G2 & $\uparrow \uparrow \uparrow$ & 0.0021 & 495 \\
\hline & G3 & $\downarrow \downarrow$ & 0.014 & 723 & G3 & & 0.33 & 347 & G3 & & 0.21 & 391 \\
\hline & G3 ER+ & $\downarrow \downarrow$ & 0.028 & 235 & G3 ER+ & & 0.58 & 96 & G3 ER+ & & 0.51 & 132 \\
\hline & G3 ER- & $\downarrow \downarrow \downarrow$ & 0.0035 & 293 & G3 ER- & $\downarrow$ & 0.13 & 109 & G3 ER- & $\downarrow$ & 0.068 & 125 \\
\hline & G3 Her2+ & & 0.67 & 87 & G3 Her2+ & & n.d. & 25 & G3 Her2+ & & 0.93 & 54 \\
\hline & G3 Her2- & $\downarrow \downarrow \downarrow$ & 0.0025 & 239 & G3 Her2- & $\downarrow$ & 0.066 & 46 & G3 Her2- & & 0.19 & 37 \\
\hline & G3 LN+ & $\downarrow \downarrow \downarrow$ & 0.00015 & 271 & G3 LN+ & & 0.32 & 122 & G3 LN+ & & 0.35 & 123 \\
\hline & G3 LN- & & 0.57 & 381 & G3 LN- & & 0.38 & 160 & G3 LN- & & 0.35 & 269 \\
\hline & $\begin{array}{c}\text { G3 ER+ } \\
\text { LN+ }\end{array}$ & $\downarrow \downarrow$ & 0.041 & 117 & $\begin{array}{c}\text { G3 ER+ } \\
\text { LN+ }\end{array}$ & & 0.22 & 40 & $\begin{array}{c}\text { G3 ER+ } \\
\text { LN }+\end{array}$ & & 0.9 & 48 \\
\hline & $\begin{array}{c}\text { G3 ER+ } \\
\text { LN- }\end{array}$ & & 0.85 & 114 & $\begin{array}{c}\text { G3 ER+ } \\
\text { LN- }\end{array}$ & & 0.36 & 54 & $\begin{array}{c}\text { G3 ER+ } \\
\text { LN- }\end{array}$ & & 0.75 & 81 \\
\hline & $\begin{array}{l}\text { G3 ER- } \\
\text { LN+ }\end{array}$ & $\downarrow \downarrow \downarrow$ & 0.0067 & 106 & $\begin{array}{l}\text { G3 ER- } \\
\text { LN+ }\end{array}$ & & 0.21 & 35 & $\begin{array}{c}\text { G3 ER- } \\
\text { LN+ }\end{array}$ & & n.d. & 27 \\
\hline & $\begin{array}{l}\text { G3 ER- } \\
\text { LN- }\end{array}$ & & 0.3 & 182 & $\begin{array}{c}\text { G3 ER- } \\
\text { LN- }\end{array}$ & & 0.31 & 72 & $\begin{array}{c}\text { G3 ER- } \\
\text { LN- }\end{array}$ & & 0.26 & 96 \\
\hline & $\begin{array}{c}\text { G3 Her2- } \\
\text { LN+ }\end{array}$ & $\downarrow \downarrow \downarrow$ & 0.0055 & 115 & $\begin{array}{c}\text { G3 Her2- } \\
\text { LN+ }\end{array}$ & & 0.18 & 30 & $\begin{array}{c}\text { G3 Her2- } \\
\text { LN+ }\end{array}$ & & n.d. & 14 \\
\hline & $\begin{array}{l}\text { G3 Her2- } \\
\text { LN- }\end{array}$ & & 0.48 & 123 & $\begin{array}{c}\text { G3 Her2- } \\
\text { LN- }\end{array}$ & & n.d. & 16 & $\begin{array}{c}\text { G3 Her2- } \\
\text { LN- }\end{array}$ & & n.d. & 23 \\
\hline \multirow[t]{6}{*}{ luminal A } & any & & 0.12 & 1764 & any & $\uparrow \uparrow$ & 0.043 & 504 & any & $\uparrow$ & 0.074 & 918 \\
\hline & ER+ & $\uparrow \uparrow$ & 0.027 & 1205 & ER+ & $\uparrow \uparrow \uparrow$ & 0.0034 & 262 & ER+ & $\uparrow$ & 0.048 & 419 \\
\hline & ER- & & 0.57 & 83 & ER- & & 0.77 & 28 & ER- & & 0.91 & 20 \\
\hline & $\mathrm{LN}+$ & $\uparrow \uparrow$ & 0.022 & 453 & $\mathrm{LN}+$ & $\uparrow \uparrow \uparrow$ & 0.00033 & 71 & $\mathrm{LN}+$ & & 0.4 & 167 \\
\hline & LN- & $\uparrow \uparrow$ & 0.042 & 999 & LN- & & 0.29 & 221 & LN- & $\uparrow$ & 0.065 & 546 \\
\hline & G3 & $\downarrow$ & 0.12 & 169 & G3 & & 0.5 & 73 & G3 & & 0.39 & 97 \\
\hline \multirow[t]{6}{*}{ luminal B } & any & $\downarrow \downarrow$ & 0.02 & 1002 & any & & 0.52 & 320 & any & & 0.77 & 361 \\
\hline & ER+ & $\downarrow \downarrow \downarrow$ & 0.0039 & 556 & $\mathrm{ER}+$ & & 0.69 & 99 & ER+ & & 0.91 & 146 \\
\hline & ER- & & 0.88 & 128 & ER- & & 0.28 & 22 & ER- & & 0.81 & 28 \\
\hline & $\mathrm{LN}+$ & $\downarrow \downarrow$ & 0.017 & 275 & $\mathrm{LN}+$ & & 0.5 & 43 & $\mathrm{LN}+$ & & 0.61 & 87 \\
\hline & LN- & & 0.63 & 446 & LN- & $\downarrow$ & 0.091 & 80 & LN- & & 0.38 & 171 \\
\hline & G3 & $\downarrow$ & 0.12 & 209 & G3 & & 0.24 & 96 & G3 & & 0.69 & 95 \\
\hline basal & any & $\downarrow$ & 0.079 & 580 & any & & 0.5 & 204 & any & & 0.23 & 219 \\
\hline subtype & ER+ & & 0.41 & 36 & ER+ & & n.d. & 14 & ER+ & & n.d. & 10 \\
\hline
\end{tabular}

(Continued) 


\begin{tabular}{|c|c|c|c|c|c|c|c|c|c|c|c|c|}
\hline subtype* & status** & $\begin{array}{l}\text { prognostic } \\
\text { value }^{* * *}\end{array}$ & RFS & patients & status & $\begin{array}{l}\text { prognostic } \\
\text { value }\end{array}$ & OS & patients & status & $\begin{array}{l}\text { prognostic } \\
\text { value }\end{array}$ & DMFS & patients \\
\hline & ER- & $\downarrow \downarrow$ & 0.038 & 339 & ER- & & 0.19 & 60 & ER- & & 0.39 & 74 \\
\hline & $\mathrm{LN}+$ & $\downarrow \downarrow$ & 0.042 & 144 & $\mathrm{LN}+$ & & 0.31 & 52 & $\mathrm{LN}+$ & & 0.46 & 48 \\
\hline & $\mathrm{LN}-$ & & 0.69 & 291 & LN- & & 0.67 & 96 & $\mathrm{LN}-$ & & 0.74 & 134 \\
\hline & G3 & & 0.17 & 263 & G3 & & 0.59 & 129 & G3 & & 0.57 & 136 \\
\hline
\end{tabular}

* Molecular subtypes were derived from gene expression profiling at KMPLOT (http://kmplot.com/analysis/). With respect to the available Her2 status by FISH (see column status), the Her2 molecular subtype is not shown.

** Protein expression of estrogen receptor (ER+, ER-) may differ from mRNA expression which is used for molecular classification.

*** Arrows indicate positive $(\uparrow)$ or negative $(\downarrow)$ prognostic value of high asporin expression. Significance $\mathrm{p}<0.01, \mathrm{p}<0.05$ and trend $\mathrm{p}<0.15$ are highlighted by three, two or one arrow, respectively.

n.d., not done for less than 30 patients; RFS, relapse free survival; OS, overall survival; DMFS, distant metastasis free survival.

A
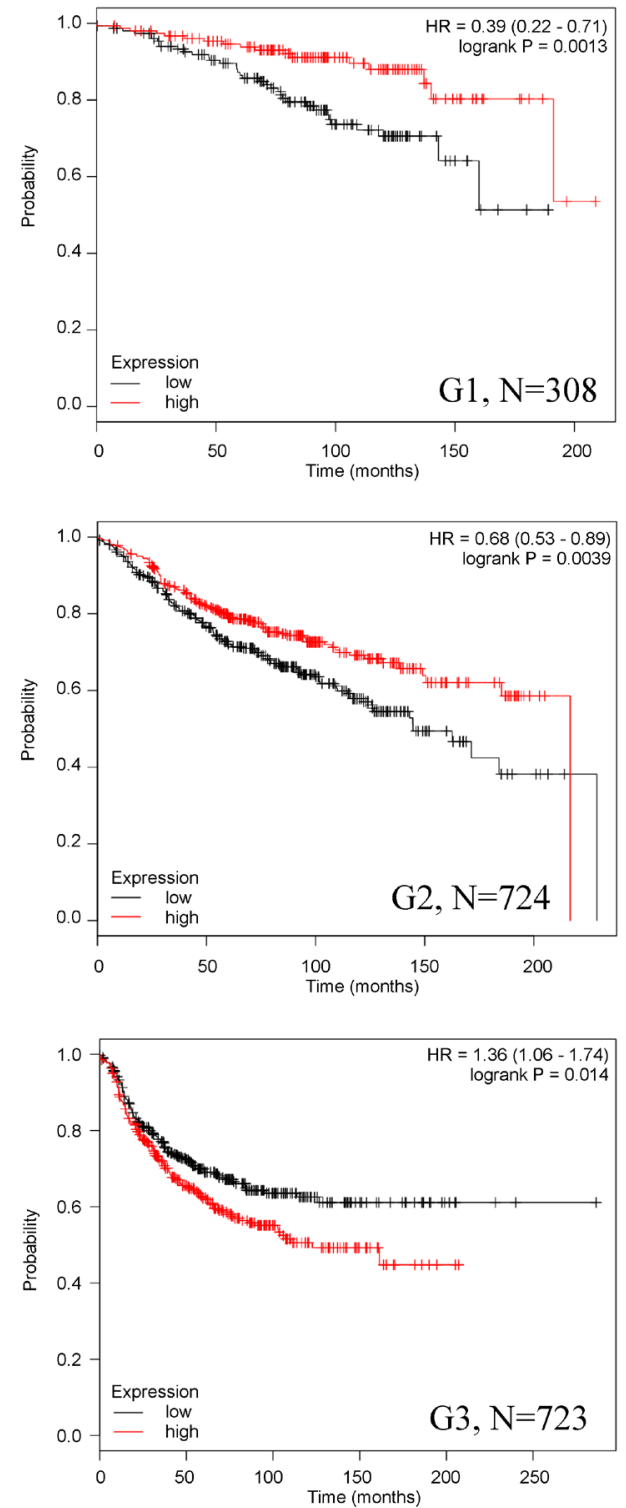

B
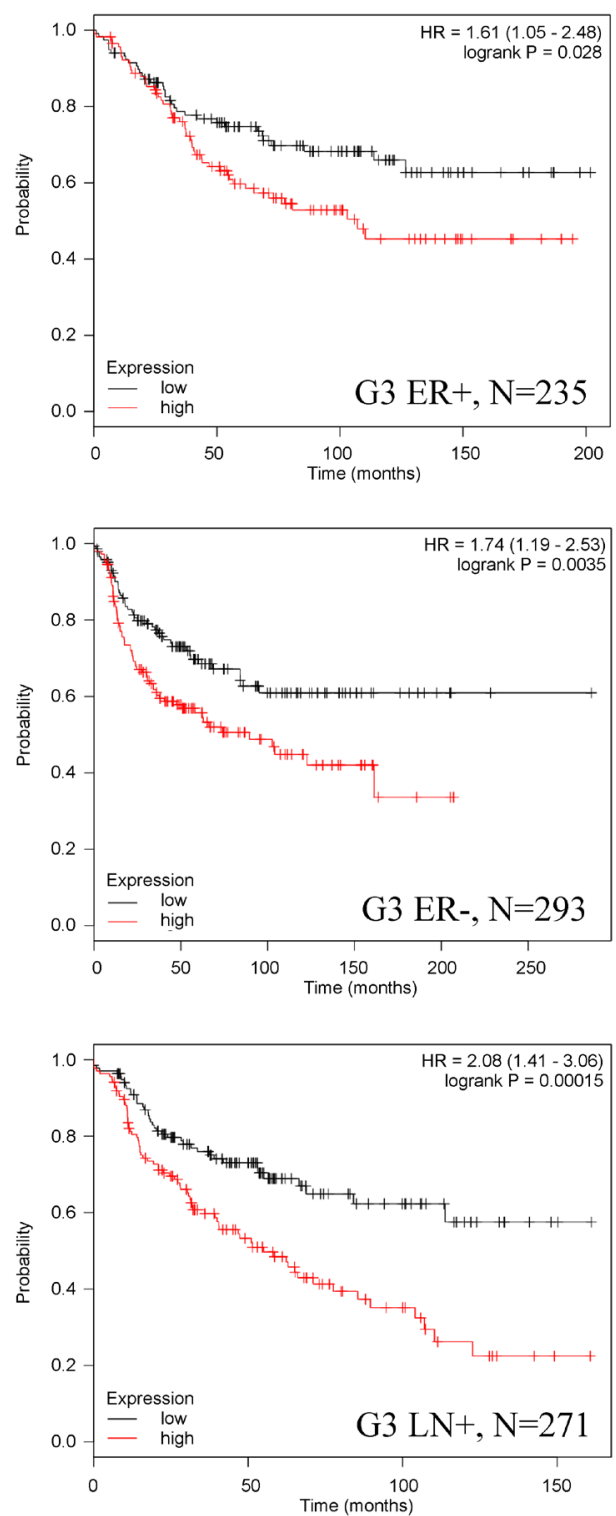

Figure 1: Asporin expression has different prognostic value in low-grade and advanced breast cancer. A. High asporin expresion associates with significantly better relapse free survival (RFS) in patients with low-grade tumors but RFS is significantly worse in patients with grade 3 tumors. B. High asporin expression is associated with significantly worse RFS both in estrogen receptor positive and negative grade 3 tumors, in particular with metastasis to lymph nodes. HR, hazard ratio; N, number of patients in the KMPLOT analysis. 
22.5 mean fold protein upregulation; mean $\Delta \Delta \mathrm{Ct} 4.03$ which corresponds to approximately 16 fold mRNA upregulation). Lack of nutrients may correspond to stress conditions for cancer cells in vivo where hypoxia also often occurs. We have tested cultivation of Hs578T in hypoxic conditions both in serum-free medium and with $10 \%$ serum, but we did not observe any consistent influence of hypoxia on asporin expression (Figure 3D, 1.1 mean fold upregulation in serum-free medium).

Asporin binds to collagen type I, inhibits its fibrillogenesis and may affect the extracellular matrix [10]. In this sense, we tested whether different 3D matrices can modulate asporin expression in Hs578T. The matrix of collagen type I $(800 \mu \mathrm{g} / \mathrm{ml})$ and Geltrex had no effect but 3D polystyrene Alvetex increased asporin expression (Figures 3B-3C; 10.0 mean fold protein upregulation; mean $\Delta \Delta \mathrm{Ct} 2.8$ which corresponds to approximately 8 fold mRNA upregulation). Neither upregulation of asporin by serum starvation nor Alvetex matrix was associated with changes in phospho-FAK (Figure 3A-3B).

\section{Downregulation of asporin inhibits invasion of Hs578T through collagen matrix}

In order to further test the importance of asporin expression in Hs578T we prepared three stable clones with shRNA against asporin. We confirmed downregulation of asporin expression (Figure 3E; mean $\Delta \Delta \mathrm{Ct} 5.3$ which corresponds to approximately 40 fold mRNA downregulation) which did not affect proliferation, adhesion, migration or spheroid growth (data not shown).
Importantly, downregulation of asporin inhibited invasion through the collagen type I matrix (Figure 3F).

We also generated stable clones of MDA-MB-231 and BT-459 cells with asporin ORF (open reading frame with myc and DKK tag) expression vectors. Expression of mRNA was comparable to Hs578T while immunoblotting detected a band with slower mobility (Figure 2; immunoblotting for MDA-MB-231 is not shown). Expression of asporin ORF did not affect proliferation, adhesion, migration or invasion of stable clones of BT-549 or MDA-MB-231 (data not shown). Interestingly, we were not able to prepare stable clones with expression vector

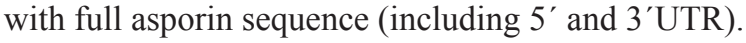

\section{Recombinant asporin enhances invasion through collagen type I matrix}

Asporin binds to collagen type I, inhibits its fibrillogenesis and may affect extracellular matrix [7, 10]. Prof. Oldberg kindly provided us with the recombinant asporin which we used in invasion assays. First, we tested invasion of the three breast cancer cell lines mentioned above through various concentrations of collagen type I matrix $(50,200$ and $800 \mu \mathrm{g} / \mathrm{ml}$; data not shown) and selected a concentration of $200 \mu \mathrm{g} / \mathrm{ml}$ which was also used by Sodek et al. [30]. MDA-MB-231 and BT-549 cells invaded faster through the collagen matrix which was prepared with the recombinant asporin in comparison with the matrix without asporin (Figure 4A-4B). Invasion of Hs578T was comparable in both matrices (data not shown).

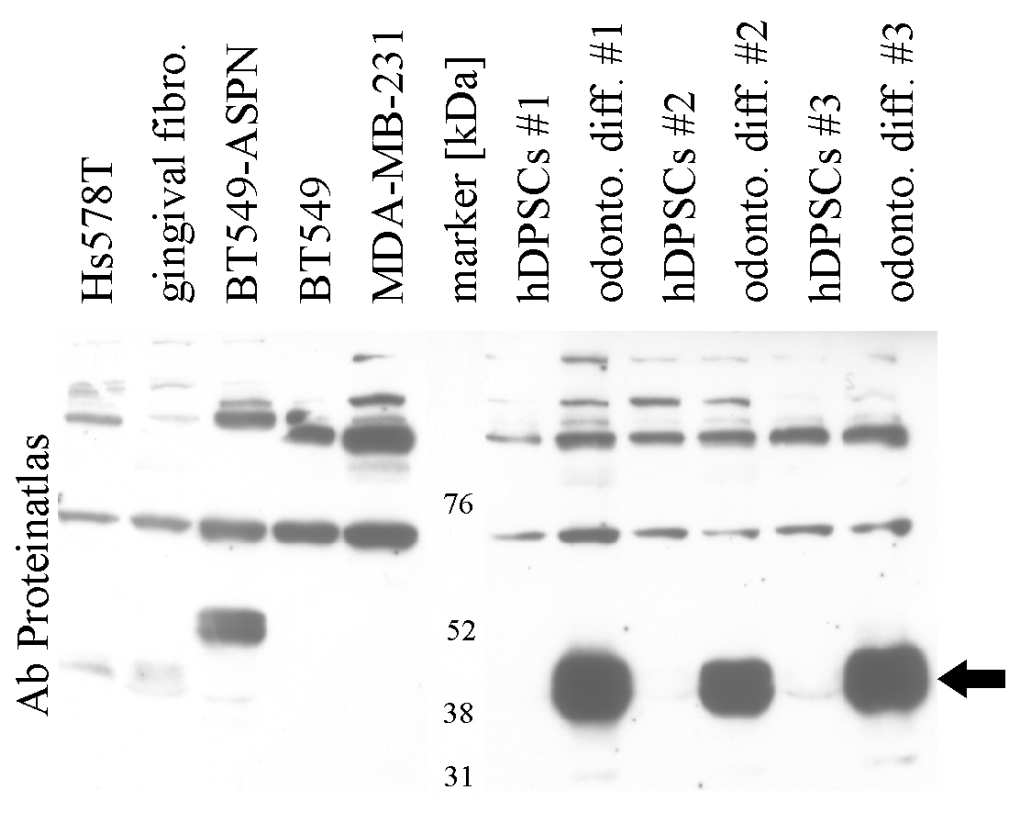

Figure 2: Validation of asporin antibody (Proteinatlas \#HPA008435) in breast cancer cells, gingival fibroblasts and human dental pulp stem cells (hDPSCs). Black arrow indicates strong upregulation of asporin in hDPSCs after odontogenic differentiation. BT-549-ASPN with stable transfected asporin open reading frame sequence display a band with higher molecular weight (a similar band was observed also in MDA-MB-231-ASPN cells, data not shown). Validation of other antibodies is provided in Supplementary Figure S2. 

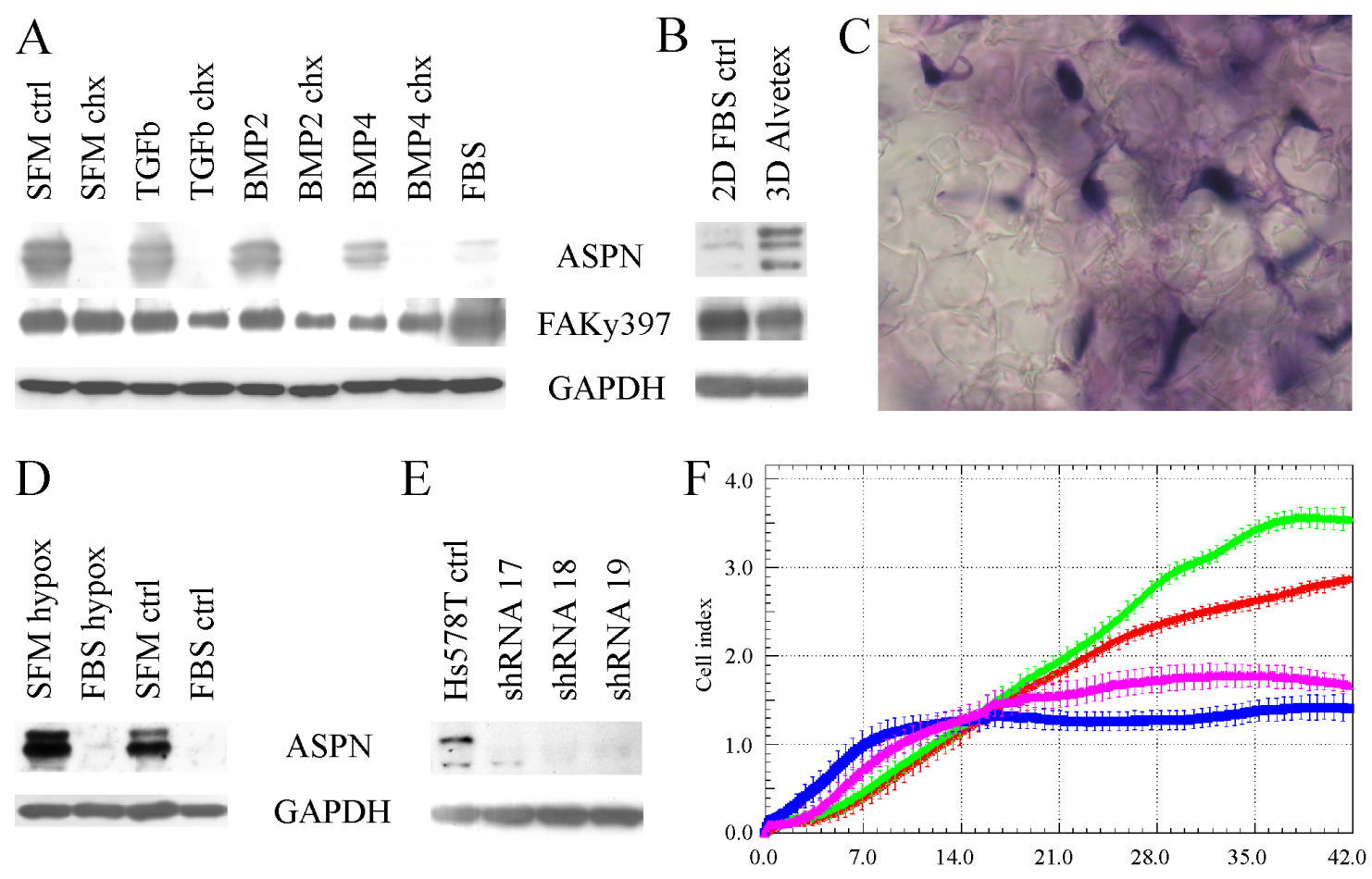

Figure 3: Glycoprotein asporin in Hs578T breast cancer cells. A. Asporin is consistently upregulated by serum starvation (SFMctrl, serum-free medium control) and downregulated by two-day treatment with $100 \mathrm{ng} / \mathrm{ml}$ bone morphogenetic protein 4 (BMP4). Mild asporin downregulation by TGF-beta was not reproduced in other experiments. BMP4 also decreased phosphorylation of focal adhesion at tyrosine 397 (FAKy397). Inhibition of translation by cotreatment with $10 \mu \mathrm{g} / \mathrm{ml}$ cycloheximide led to downregulation of asporin but not of FAK. All treatments were performed in serum free media for 48 hours. B. Expression of asporin is upregulated by 12-day cultivation of Hs578T cells in Alvetex polystyrene scaffold (3D) in comparison to normal 2D conditions. C. Formallin-fixed paraffin-embedded Hs578T cells (stained with hematoxylin-eosin) in polystyrene Alvetex scaffold (transparent stellar shapes; magnification 1000x). D. Four-day cultivation of Hs578T cells in hypoxic conditions does not consistently change asporin expression. E. Expression of asporin is successfully downregulated with three different shRNAs. F. Invasion of Hs578T cells (parental cells are displayed in green, control cells with scrambled shRNA are in red) through collagen matrix is inhibited by shRNAs 17 and 19 (blue and purple, respectively). Similar inhibition was observed also for the shRNA 18 (data not shown). Reading of cell index was every 10 minutes up to 42 hours with the real time cell monitoring xCELLigence instrument (error bars indicate standard deviations from quadruplicate measurement). All experiments were performed at least three times and representative blots/chart are shown.
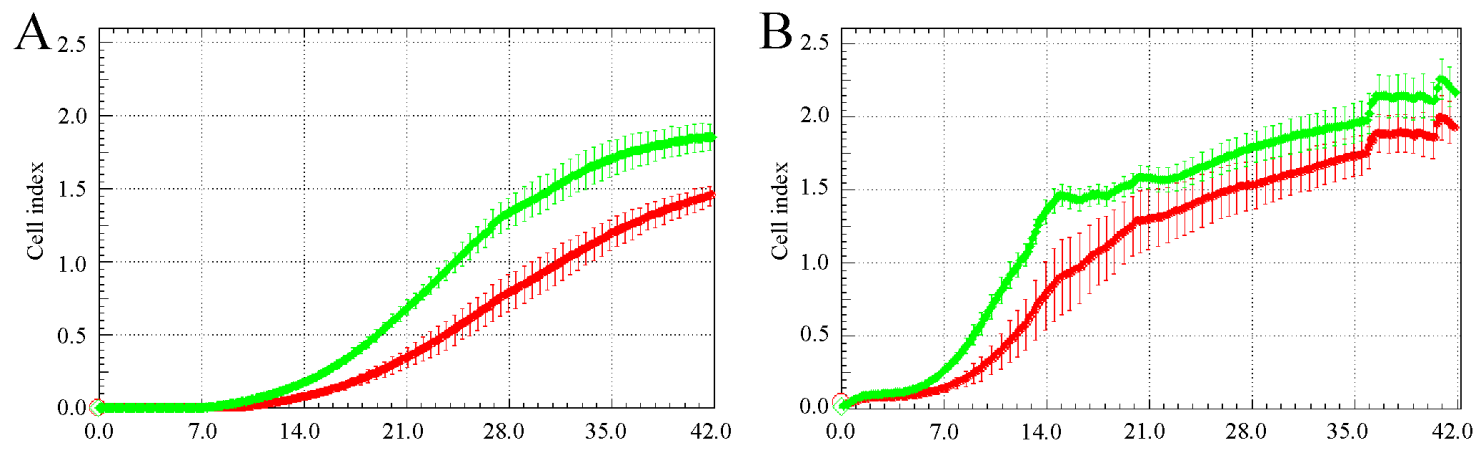

Figure 4: Recombinant asporin enhances invasion of MDA-MB-231 A. and BT-549 B. breast cancer cells through collagen matrix. Both models were seeded at a density of 75000 cells per well into CIM plates coated by collagen stiffened in presence (green) or absence (red) of $10 \mathrm{nM}$ recombinant asporin. The bottom chambers were filled with complete medium containing $10 \%$ FCS (fetal calf serum) as a chemoattractant. Reading of cell index was every 10 minutes up to 42 hours with the real time cell monitoring xCELLigence instrument (error bars indicate standard deviations from quadruplicate measurement). All experiments were performed at least three times and representative charts are shown. 


\section{RNA scope in situ hybridization detects asporin in cancer associated fibroblasts}

We have identified asporin as a novel breast cancer related protein by laser microdissection and microarray analysis [12], in particular in invasive lobular carcinomas. However, asporin has been repeatedly reported to be expressed by cancer associated fibroblasts (CAFs) or other stromal cell types [15, 23, 24, 25]. Although laser
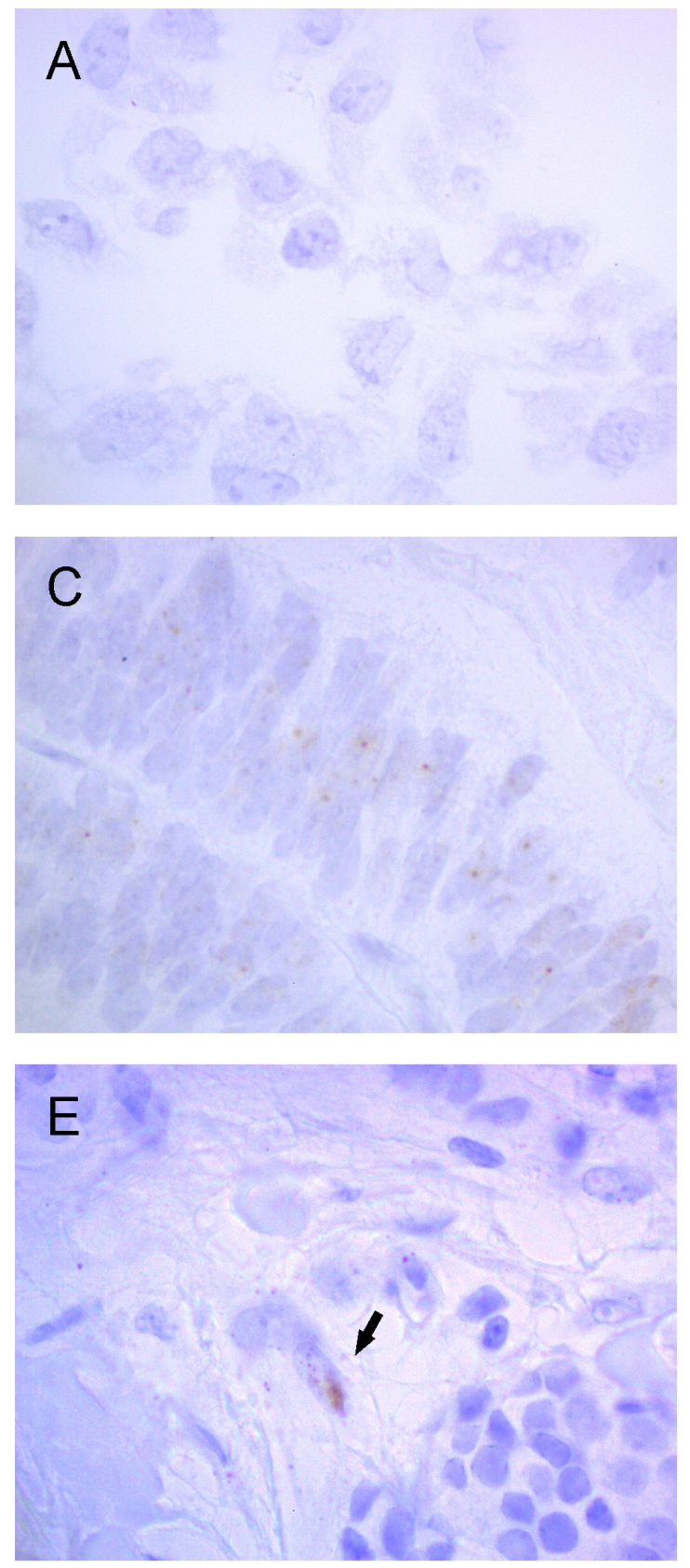

microdissection is designed for single cell isolation we cannot exclude the possible capturing of adjacent cells, in particular in invasive lobular cancers which may grow in thin lines. As there is no reliable antibody for immunohistochemistry, we decided to use RNA scope technology with gene-specific probe pairs for detection of asporin in breast cancer tissues. As a positive control (Figure 5) we used endometrium (Supplementary Figure S4) and the above mentioned hDPSCs after odontogenic
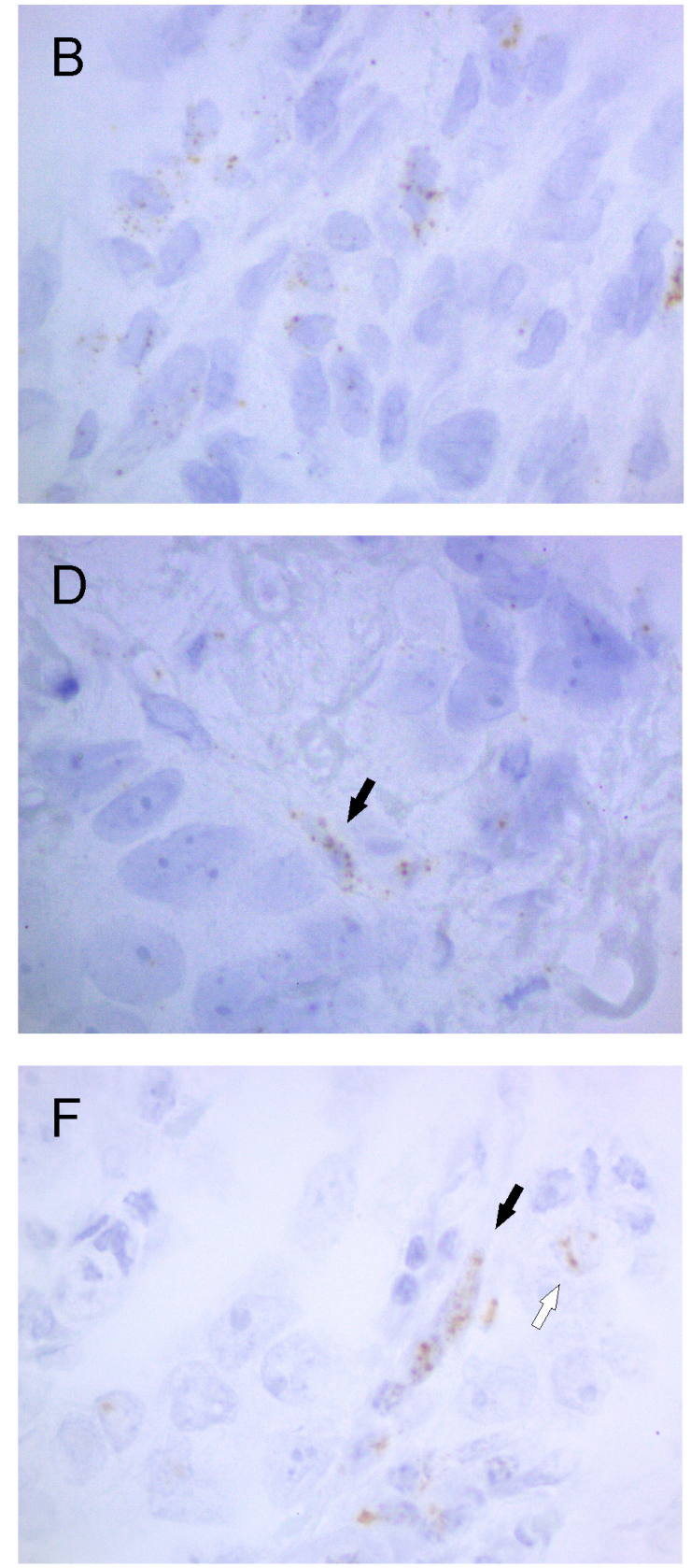

Figure 5: Asporin is detected by RNA scope in situ hybridization in invasive breast cancer. Human dental pulp stem cells before $\mathbf{A}$. and after B. odontogenic differentiation, as well as endometrium $\mathbf{C}$., were used as positive controls. Specific dot-like positivity was found in cancer associated fibroblasts both in ductal D. and lobular E-F. invasive carcinomas (black arrows). Asporin positivity was rarely observed also in cancer cells (F, white arrow). Magnification is $1000 \mathrm{x}$ while lower magnification (400x) of the same samples is provided in the Supplementary Figure S5. 
differentiation. Next, we hybridized 43 lobular and 7 ductal invasive breast cancer tissues. However, frequencies of specific dot-like signals were very low which precluded statistical analysis. Asporin dot-like positivity was found in CAFs both in ductal and lobular invasive carcinomas (Figure 5 and Supplementary Figure S5).

\section{Downregulation of asporin in cancer associated fibroblasts attenuates their coordinated invasion with breast cancer cells}

We have tested three different CAFs from patients with grade 3 breast cancer (full details are in the Methods section) and selected those with the fastest invasion and proliferation for knock-down and co-culture experiments with T47D cells. This breast cancer cell line has low invasive potential alone and represents luminal B subtype [31] (please note poor RFS of luminal B patients with high asporin expression in Table 1). Transwell experiments indicated coordinated invasion of CAFs with T47D cells which was attenuated by asporin knock down in CAFs (Figure 6A) (Figure 6B and 6D).

Similarly to Hs578T, asporin expression was enhanced in CAFs by their 3D culture in Alvetex scaffold (Figure 6C). Analysis of aspartic acid (D) repeat length of asporin revealed that our breast CAFs have D13/
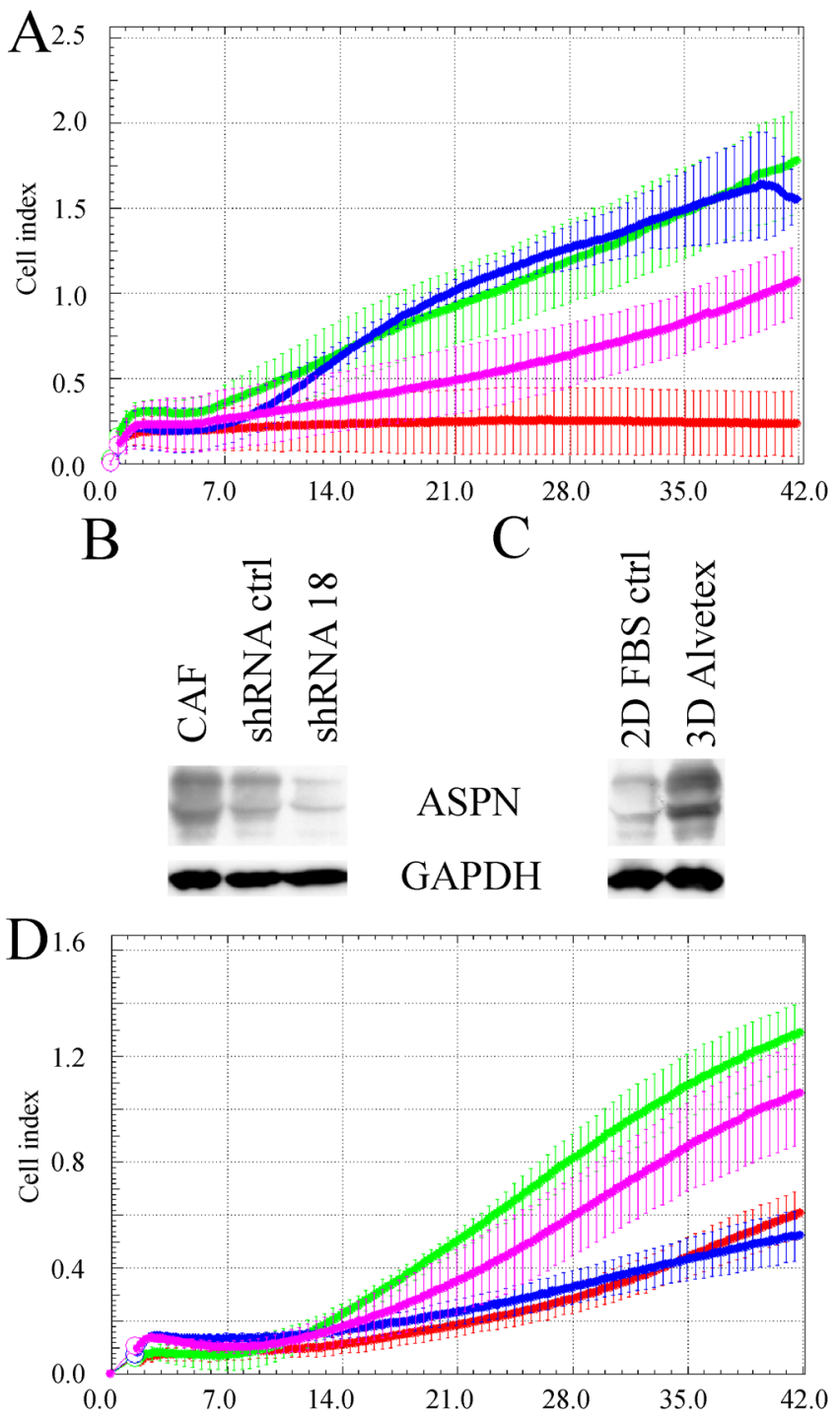

Figure 6: Invasion of breast cancer associated fibroblasts and T47D cells is attenuated by asporin downregulation. A. Transwell experiment indicate coordinated invasion of cancer associated fibroblasts with T47D cells through extracellular matrix composed of collagen, matrigel and crosslinking ribose $(70000 \mathrm{CAFs}$, green; 70000 T47D, red; CAFs + T47D, 35000 each, blue; 35000 CAFs, purple). Western blot analysis shows downregulation of asporin by shRNA B. and its upregulation upon 3D cultivation of CAFs in Alvetex polystyrene scaffold C. D. Downregulation of asporin attenuated invasion of CAFs and T47D cells (70000 CAFs shRNA ctrl, green; 70000 CAFs shRNA18, red; CAFs shRNA ctrl + T47D, 35000 each, purple; CAFs shRNA 18 + T47D, 35000 each, blue). All experiments were performed three times and representative blots/charts are shown. 
D14 genotype which has recently been associated with poor metastasis-free survival of prostate cancer patients (Supplementary Figure S6) [32].

\section{DISCUSSION}

The need for complex 3D culture models to unravel novel pathways and identify accurate biomarkers in breast cancer has been recently reviewed [33]. We have observed asporin upregulation during 3D culture of Hs578T cells in polystyrene scaffold Alvetex, but not in collagen or Geltrex matrices. Similarly, expression of tropomyosin kinase 2 was increased by 3D cultivation on collagencoated polystyrene scaffold Alvetex [34] in comparison to $2 \mathrm{D}$ culture. Stiffness of the matrix is a major factor which could affect tumor progression $[1,35]$. Polystyrene scaffold is stiffer than collagen or Geltrex matrices and may better simulate solid stress in tumors in vivo.

In contrast to chondrocytes or peridontal ligament cells $[28,29]$ we found no asporin modulation by TGFbeta or BMP2 in Hs578T cells. Nevertheless, asporin was slightly downregulated by BMP4. Similarly to BMP7, expression of BMP4 is low in invasive breast cancer and its signalling has been implicated in the maintenance of tumor dormancy [36-38]. Unexpectedly, we observed upregulation of asporin in serum-free cultivation. We speculate that this induction could lead to enhanced motility towards better sources of nutrients. Upregulation by starvation has also been reported for other proteins in cancer, e.g. glucose regulated chaperones [39, 40].

MDA-MB-231 and BT-549 cells invaded faster through collagen matrix which was prepared with the recombinant asporin in comparison to the matrix without asporin. This may be related to less dense matrix due to inhibition of collagen fibrillogenesis by asporin [10]. Invasion of Hs578T cells, which is accompanied by endogenous asporin production, was not further enhanced in the matrix with recombinant asporin. On the contrary, asporin downregulation decreased invasion of Hs578T cells through the collagen matrix. As shown by Satoyoshi et al. [24] asporin itself can promote invasion of both cancer cells and cancer associated fibroblast by interaction with CD44 and activation of Rac1. We have not observed any phenotypic change of BT-549 and MDA-MB-231 cells after stable transfection, however, asporin from ORF sequence may not reflect its native form.

We found asporin dot-like positivity mostly in cancer associated fibroblasts both in ductal and lobular invasive carcinomas which is in concordance with studies both from breast or other solid tumors such as prostate or gastric cancer [23, 24]. Cancer associated fibroblasts resemble myofibroblasts with smooth muscle actin which is also expressed in so called myoepithelial Hs578T [41]. Interestingly, Hs578T and SNB-75 cancer cells with asporin expression have the highest expression of smooth muscle actin (Supplementary Figure S1B). Asporin has also been reported to be expressed by gastric cancer cell lines and to enhance their oncogenic properties [42]. As asporin belongs to secreted proteins, regulation of its expression both in CAFs and cancer cell is relevant for alteration of the tumor microenvironment.

Maris et al. [25] have recently described the tumor suppressive potential of asporin in several breast cancer models. This may be true for a subset of breast cancer patients. However, in silico data mining on a large cohort of breast cancer patients showed that high asporin expression is associated with significantly worse RFS both in estrogen receptor positive and negative grade 3 tumors, even with metastasis to lymph nodes. Asporin was also associated with worse RFS in the chemotherapy treated basal subtype and in the untreated luminal B subtype. Van't Veer et al. [43] have recently assembled 72 breast cancer-related gene expression datasets, containing approximately 5700 samples altogether, where asporin is included in an extracellular matrix module comprising 58 genes. Importantly, asporin was found as one of the most upregulated genes in bone metastases of breast and prostate cancer $[17,44]$. This is in accord with its primary function in skeletal development (mainly bones, cartilage and teeth), regulation of collagen fibrillogenesis and induction of mineralization [6, 7, 10, 45]. Hurley et al. [32] have recently described different metastatic potential of prostate cancer related to the polymorphism of aspartic acid (D)-repeat of asporin, which may also be important in breast cancer. D14 allele (heterozygous with D13 as well as in combination with any other allele) was associated with poor patient outcome, which is in line with decreased invasion of our breast CAFs upon asporin downregulation (genotype D13/D14). The unique asporin polyaspartate repeat binds calcium [10] and the D14 allele was also linked to predisposition for knee joint osteoarthritis whereas the D13 allele was more prevalent in healthy individuals [46]. The role of other alleles, such as D15 (homozygous in breast cancer cell line Hs578T) or D16 (heterozygous with D13 in bacteria used for production of recombinant asporin) awaits elucidation. Maris et al. [25] used transcript variant 1 with 13 aspartic acids (NM_017680.4) for both in vitro and in vivo experiments and therefore their results are in good concordance with the study of Hurley et al. [32] which decribed tumor suppressive effects of the D13 allele in prostate cancer.

In conclusion, we found that asporin can be downregulated by bone morphogenetic protein 4 in Hs578T cells and its upregulation may be facilited by serum-free cultivation or by three dimensional growth. Downregulation by shRNA inhibited invasion of Hs578T as well as of CAFs and T47D cells while invasion of asporin-negative MDA-MB-231 and BT549 breast cancer cells through collagen type I was enhanced by recombinant asporin. In contrast to these observations, tumor suppressive effects of asporin were published by others. Importantly, opposing effects of different asporin alleles 
have recently been reported in prostate cancer. Its dual role is also documented by our metaanalysis of publicly available data which found asporin to be associated with better prognosis in low-grade tumors but not in high-grade breast cancer. Besides other investigations, large scale analysis of aspartic acid (D)-repeat polymorphism will be needed for clarification of asporin dual role in progression of breast cancer.

\section{MATERIALS AND METHODS}

\section{Cell culture}

Authenticated and mycoplasma-free breast cancer cell lines were used for all experiments. Hs578t cells, obtained from ECACC (Salisbury, UK), were grown in Dulbecco's Modified Eagle's Medium (DMEM; Life Technologies, Carlsbad, CA) supplemented with $10 \%$ foetal bovine serum (FBS, ThermoFisher, MA, USA), 1\% penicillin/streptomycin (Life Technologies) and insulin $(10 \mu \mathrm{g} / \mathrm{ml})$ (Life Technologies). MDA-MB-231, BT-549 and T47D, obtained from American Type Culture Collection (Rockville, MD, USA), were cultivated in DMEM supplemented with $10 \%$ FBS and 1\% penicillin/ streptomycin.

Normal human gingival fibroblasts (kindly provided by prof. Jitka Ulrichova from Department of Medical Chemistry and Biochemistry at Palacky University Olomouc) were obtained from medically healthy donors who were clinically free of periodontal disease. Samples of gingiva were obtained from patients undergoing surgical removal of third molars at the Department of Oral and Maxillofacial Surgery (University Hospital, Olomouc). The tissue acquisition protocol adhered to the requirements of the local Ethics Committee. All patients had signed written informed consent.

The gingival tissues were washed three times in phosphate buffered saline (PBS) containing antibiotics (pamycon and colinomycin). The excised gingiva were cut into $1 \mathrm{~mm}$ pieces, plated in Petri dishes (10 cm diameter) and cultured in DMEM with 10\% FBS and 1\% penicillin/ streptomycin. Explants were incubated in humidified atmosphere with $5 \% \mathrm{CO}_{2}$ at $37^{\circ} \mathrm{C}$. Cells were fed weekly until the fibroblasts reached confluence. After 4-6 weeks cell cultures were trypsinized and transferred into $75 \mathrm{~cm}^{2}$ cultivation flasks. Cells were used between the 3 and 10 passages for experiments.

\section{Breast cancer associated fibroblasts}

Isolation of primary breast cancer associated fibroblasts was performed according to modified protocol from Giannoni et al. [47, 48]. Tissue samples were obtained from patients undergoing surgical removal of breast cancer at Masaryk Memorial Institute (Brno, Czech
Republic). The tissue acquisition protocol adhered to the requirements of the local Ethics Committee and all patients had signed written informed consent. Pieces of breast cancer tissue were minced and put on a $100 \mathrm{~mm}$ tissue culture dish. Sterile microscopic slide was put over the tissue pieces, slightly pushed, and overlaid with DMEM medium supplemented with 20\% FBS, 2\% penicillin/ streptomycin, $100 \mu \mathrm{g} / \mathrm{ml}$ kanamycin (Serva, Germany), $2.5 \mu \mathrm{g} / \mathrm{ml}$ amphotericin B (ThermoFisher Scientific). Approximately 3 weeks after initial seeding of tissue pieces, the microscopic slide was removed and fibroblasts were further maintained as a regular cell culture. After approximately two weeks in culture, the cultivation medium was changed to DMEM with $10 \%$ FBS and $1 \%$ penicillin/streptomycin. To confirm homogeneity of isolated fibroblasts (denoted as BCAF3, BCAF4 and BCAF5), we performed FACS analysis of three selected surface fibroblast markers using BD FACSVerse flow cytometer. Cell suspension obtained by trypsinisation was stained with primary antibodies against FAP (human fibroblast activation protein alpha, MAB3715, R\&D Systems), FSP (fibroblast surface protein, F4771, SigmaAldrich), followed by staining with secondary antibody Alexa Fluor 488 conjugated donkey anti-mouse $\operatorname{IgG}(\mathrm{H}+\mathrm{L})$ (A21202, ThermoFisher Scientific); and primary antibody anti-fibroblast FITC (130-100-134, Miltenyi Biotec). Dead cells were excluded from the analysis using LIVE/ DEAD Fixable Far Red Dead Cell Stain Kit (L10120, ThermoFisher Scientific). Analysis showed uniform positivity for all three markers and simultaneously, no positivity for non-fibroblast markers EpCAM (324220, BioLegend), CD31 (303104, BioLegend), and CD45 (304054, BioLegend) was detected.

We have isolated fibroblasts from three patients with invasive breast cancer, no special type (samples were denoted as BCAF3, BCAF4 and BCAF5) with the following clinicopatological parameters: BCAF3 - grade 3, pT2 (25 mm), pN0, M0, Her2 positive, ER 0\%, PR 0\%, AR 100\%, Ki67 52\%; BCAF4 - grade 3, pT2 (35mm), $\mathrm{pN} 1 \mathrm{a}(3 / 15), \mathrm{M} 0$, Her2 negative, all ER, PR and AR 100\%, Ki67 30\%; BCAF5 - grade 3, pT3 (55mm), pN0, Her2 negative, ER 100\%, PR variable (0-3-80\%), AR 80\%, Ki67 55\%. BCAF4 grew fastest and were more invasive than BCAF5 (data not shown; BCAF3 were not tested for invasion due to their slow proliferation). BCAF4 (passages from 9 to 11) were used as a model of cancer associated fibroblasts in all experiments.

Transient asporin knockdown in BCAF4 (specific sh18 and control scrambled shRNA; please see the sequences below) was performed with Viromer $^{\circledR}$ transfection reagent (Lipocalyx, Hall, Germany) according to manufacturer protocol. Standard medium was changed after $12 \mathrm{hrs}$ and one day later the cells were starved in serum free medium for $6 \mathrm{hrs}$ before invasion experiments (see below). 


\section{Human dental pulp stem cells and odontogenic differentiation}

The isolation and culture of dental pulp stem cells (hDPSC) were performed according to protocol described previously [49]. Impacted wisdom teeth were obtained from healthy donors with informed consent at the Department of Dentistry under approved guidelines of the Ethical Committee of the Faculty Hospital in Hradec Kralove. For odontogenic differentiation, hDPSCs were cultured until confluence and then incubated with alphaMEM supplemented with $10 \mathrm{mM}$ beta-glycerolphosphate, $50 \mu \mathrm{M}$ ascorbic acid and $0.1 \mu \mathrm{M}$ dexamethasone for one week [26].

\section{Experimental treatments of $\mathrm{Hs578T}$ cells}

Multiple treatments which could modify expression of asporin in Hs578T were tested. TGF $\beta$ (transforming growth factor $\beta$ ) in concentration of 10 $\mathrm{ng} / \mathrm{ml}$, BMP2 and BMP4 (bone morphogenetic protein 2 and 4) in concentration $100 \mathrm{ng} / \mathrm{ml}$ were added to 24 hrs starved Hs578t cells in serum deprived media for $48 \mathrm{hrs}$. Additionally, each cytokine was combined with cycloheximide treatment (Sigma-Aldrich, Germany) in final concentration $10 \mu \mathrm{g} / \mathrm{ml}$ for the same period of time. Long term cultivation of $\mathrm{Hs} 578 \mathrm{t}$ cells in presence of $1 \mu \mathrm{M}$ dexamethasone (Sigma-Aldrich) was for three weeks. Expression of asporin was also monitored after 4 day cultivation of Hs578T cell under hypoxic conditions with $3 \% \mathrm{O}_{2}$.

Cultivation of Hs578t in 3D was performed with polystyrene scaffold Alvetex ${ }^{\circledR}$ (Reinervate, UK), Geltrex $^{\circledR}$ (Life Technologies) or collagen type I (Purecol ${ }^{\circledR}$, Advanced BioMatrix, Carlsbad, CA) and lasted for 12 days with medium exchange every 4 days. Geltrex thin gel method was performed by mixing $500 \mu \mathrm{l}$ of Geltrex with $1000 \mu \mathrm{l}$ cultivating media followed by 1.5 hour incubation in $37^{\circ} \mathrm{C}$. Collagen in a concentration of 800 $\mu \mathrm{g} / \mathrm{ml}$ was diluted to $150 \mathrm{mM} \mathrm{NaCl}$ buffered with $20 \mathrm{mM}$ Hepes ( $\mathrm{pH}$ 7.4), and left to solidify in $37^{\circ} \mathrm{C}$ in cell culture incubator.

\section{Generation of stably transfected cell lines}

For asporin overexpression MDA-MB-231 and BT-549 were transfected either with ASPN full length sequence (TrueClone, pCMV6-AC, Origene) or with open reading frame (TrueORF, pCMV6, Origene) sequence using Neon Transfection System (Life Technologies). Stable cell lines were selected with $0.5 \mathrm{mg} / \mathrm{ml}$ geneticin for 2 weeks and then kept under low selection pressure at $0.1 \mathrm{mg} / \mathrm{ml}$ geneticin.

For asporin knockdown Hs578t cells were similarly transfected with short hairpin RNAs (sh17 AGT TGA AAT ACC TCC AGA TAA TCT TCC TT, sh18 TCC AAC AGT GCC AAA GAT GAA GAA ATC TT or sh19 CGA GTA
TGT GCT CCT ATT ATT CCT GGC TT in pRS plasmid, OriGene) and selected with $1 \mu \mathrm{g} / \mathrm{ml}$ puromycin. Both overexpression and knockdown of ASPN were checked by RT-PCR and western blotting. Control cells were transfected with empty pRS plasmid or scrambled shRNA (GCA CTA CCA GAC CTA ACT CAG ATA GTA CT; Origene \#TR30012).

\section{Adhesion, proliferation and migration assays}

Experiments were carried out using xCELLigence Real-Time Cell Analyzer (RTCA) DP instrument (Roche diagnostic, GmbH, Germany). For adhesion assay 40000 cells were seeded on E-plate 16 surface and increasing cell index was monitored every 30 seconds for $4 \mathrm{hrs}$, followed by recording cell proliferation for additional $64 \mathrm{hrs}$.

For migration monitoring, fully confluent cell population in a standard cultivation medium supplemented with $10 \mu \mathrm{g} / \mathrm{ml}$ mitomycin C (Roche) was scratched by pipette tip. Migrating cell populations were monitored every second hour for $24 \mathrm{hrs}$. Experiments were repeated at least three times.

\section{Invasion assays}

Invasion assays were carried out using xCELLigence Real-Time Cell Analyzer (RTCA) DP instrument (Roche). Parental breast cancer cell lines (MDA-MB-231, BT-549 and Hs578t) were tested with collagen I matrix prepared with or without recombinant asporin (kind gift from Professor Åke Oldberg, University of Lund). Bottom side of CIM plate inserts (Roche/Acea, CA, USA) was pre-coated with $30 \mu \mathrm{l}$ of cooled $200 \mu \mathrm{g} / \mathrm{ml}$ collagen I (Purecol ${ }^{\circledR}$, Advanced BioMatrix, Carlsbad, CA) prepared as described by Kalamajski et al. [10]. Resulting aqueous phase was pipetted off after 30 minutes leaving a thin collagen film. The upper side of the inserts was coated with $30 \mu \mathrm{l}$ of cooled collagen I with or without $10 \mathrm{nM}$ recombinant asporin and the solution was incubated at $37^{\circ} \mathrm{C}$ for $6 \mathrm{hrs}$. The lower chamber of the CIM plate was filled with $170 \mu 10 \%$ FCS DMEM as a chemoattractant. Background signal was measured after addition of 30 $\mu \mathrm{l}$ of serum-free media per well followed by 1 hour of incubation at $37^{\circ} \mathrm{C}$. Cells which were starved in medium without serum for $6 \mathrm{hrs}$ were harvested and seeded in amount of 75000 cells per insert well. Cell index was monitored every 10 minutes for $42 \mathrm{hrs}$.

For stably transfected cells (MDA-MB-231, BT-549 and Hs578t) the invasion barrier was prepared from 200 $\mu \mathrm{g} / \mathrm{ml}$ pure collagen I (collagen G1, Matrix BioScience GmbH Germany) and CIM plate was coated as described above. Collagen solution in the upper part of wells was incubated for 1 hour at $37^{\circ} \mathrm{C}$ and then 75000 starved cells were added. Increasing cell index was recorded every 10 minutes for $24 \mathrm{hrs}$. All experiments were repeated at least three times. 
Modified protocol was used for CAFs and T47D cells. The upper side of the inserts was coated with $30 \mu \mathrm{l}$ of mixture of $200 \mu \mathrm{g} / \mathrm{ml}$ neutralized collagen I (Advanced BioMatrix, Carlsbad, CA), Matrigel $\AA$ (200 $\mu \mathrm{g} / \mathrm{ml}$; Corning, MA, USA) and $15 \mathrm{mM}$ D-ribose (SigmaAldrich) and then incubated at $37^{\circ} \mathrm{C}$ for $1 \mathrm{hr}$ [50]. Lower chamber of the CIM plate was filled with $170 \mu 10 \%$ FCS DMEM as a chemoattractant. Collagen-Matrigelribose clot was overlaid by $30 \mu \mathrm{l}$ of serum-free media. Assembled coated CIM plates were left at $37^{\circ} \mathrm{C}$ in the incubator for $1 \mathrm{hr}$ followed by reading background signal. Starved cells were harvested and seeded in amount of 70000 cells per insert well or 35000 per cell line in coculture experiments. Cell index was monitored every 10 minutes for 42 hrs. Experiments were repeated three times.

\section{Spheroid assay}

Spheroid cell culture was performed by the liquid overlay method [51]. Briefly, all cell models were seeded at 10000 cells on convex face of $1.5 \%$ agarose LE (Promega, WI, USA) in DMEM. The plate was then spun at $1000 \mathrm{rpm}$ for 15 minutes to induce cell aggregation and subsequently each well was overlayed by $100 \mu \mathrm{l}$ of standard cultivation media [52]. Formation of mammospheres was recorded after 4 days.

\section{In situ hybridization by RNAscope and immunohistochemistry}

Archival tissue samples of 50 invasive breast cancer, among them 43 invasive lobular (ILC) and 7 invasive ductal carcinomas (IDC) were obtained from patients between years 1999 and 2006. We have previously found high levels of asporin in ILC than IDC [12], therefore, ILC cases were specifically selected to reach sufficient sample size. The study was approved by the Ethics Committee of the Faculty of Medicine and Dentistry. Control cells from in vitro culture were homogeneously distributed in an agarose gel matrix, creating an artificial tissue, and then formalin-fixed and paraffin-embedded [53]. These controls were used also for immunohistochemistry validation (Supplementary Table S2), however, the results didn't reflect the mRNA levels of asporin in any method tested (antigen retrieval by boiling either in a microwave for 20 min in citrate buffer pH6 or in a water bath in EDTA pH9; visualization by DAB chromogen and Dual Link secondary antibody, Dako) [13].

In situ hybridization for asporin RNA was performed using the RNAscope ${ }^{\circledR} 2.0$ kit according to the manufacturer's manual (Advanced Cell Diagnostics, USA; [54]. Briefly, $5 \mu \mathrm{m}$ formalin-fixed, paraffin-embedded tissue sections were deparaffinized in xylene and pretreated with heat (15 minutes, boiling in water bath) and protease (undiluted protease solution, 30 minutes, $40^{\circ} \mathrm{C}$, DAKO hybridizer). Length of the main hybridization step was increased from 2 to $3 \mathrm{hrs}\left(40^{\circ} \mathrm{C}\right)$. Then signal amplification system which included hybridization with preamplifier, amplifier and label probes, and subsequently chromogenic detection with DAB (3,3'-diaminobenzidine) was used. Positive staining was identified as brown punctate dots in the cell. Negative control probes (DapB) and positive control probes (POLR2A) were also included for each examined slide.

With respect to the RNA scope technology, several aspects should be commented upon. The frequency of dotlike positivity was low, while other types of positivities occurred, for example in areas with inflammation or rare homogenous nuclear positivity in negative control. The results may also be affected by variability of patient samples. Although all samples were fixed and embedded in our pathology laboratory according to standard protocols, we observed differences in signals with RNA scope positive control. Dreyer et al. [55] compared RNA scope with DNA in situ hybridization and PCR detection of HPV infections. Surprisingly, RNA scope signals occurred even after digestion with RNase. In our opinion, RNA scope technology may support results obtained by other methods but is not a robust enough method for routine use as yet.

\section{Mass spectrometry}

Cells were lysed and $200 \mu \mathrm{g}$ of proteins was separated on SDS-PAGE as described below. Gel was coomassie stained and relevant molecular weight bands were excised, destained, reduced by $50 \mathrm{mM}$ Tris(2carboxyethyl) phosphine hydrochloride (Sigma-Aldrich), alkylated by $50 \mathrm{mM}$ Iodoacetamide (Sigma-Aldrich) and digested with proteomic grade trypsin (Promega) at $37^{\circ} \mathrm{C}$ overnight. Mass spectrometric analysis was performed on an Orbitrap Fusion (ThermoFisher Scientific) instrument fitted with a Proxeon Easy-Spray ionization source, coupled to an Ultimate 3000 RSLCnano chromatograph. Ten microliter of sample was loaded on a $\mu$-Precolumn C18 PepMap $100(300 \mu \mathrm{m}$ x 5 mm, $5 \mu \mathrm{m}, 100 \dot{A}$ pore size) desalting column (ThermoFisher Scientific) "inline" with a PepMap RSLC (75 $\mu \mathrm{m}$ x $50 \mathrm{~cm}, 3 \mu \mathrm{m}, 100$ A pore size) analytical column (ThermoFisher Scientific) heated at $35^{\circ} \mathrm{C}$. The peptides were subsequently separated on the analytical column by ramping the organic phase from $5 \%$ to $35 \%$ during a total run time of 165 minutes. The aqueous and organic mobile phases were $0.1 \%$ formic acid diluted in water or acetonitrile, respectively. There were two parallel experiments running simultaneously on mass spectrometer. The first one was single FTMS scan with resolution was set to 120,000 and precursor ions were scanned across an $\mathrm{m} / \mathrm{z}$ range of 400- 1600 . The second experiment was targeted MS2 with HCD collision and Orbitrap detector. Resolution was set to 30,000 and HCD collision energy to $35 \%$. The transitions of most suitable peptides were designed and resulting spectra were evaluated in Skyline-daily 2.6.1.6899 software [56]. 


\section{Production of recombinant asporin}

One milliliter aliquot of frozen bacterial culture containing the plasmid carrying the gene for asporin was thawed and suspended in $100 \mathrm{ml}$ of LB medium (10 $\mathrm{g} \mathrm{NaCl}, 10 \mathrm{~g}$ tryptone, $5 \mathrm{~g}$ yeast extract per liter) with kanamycin $(75 \mathrm{mg} / \mathrm{L})$ and incubated overnight on a heated rotation shaker $\left(37^{\circ} \mathrm{C}\right)[10]$. The next day this starting culture was added to 1 liter of fresh LB medium containing kanamycin. The culture was again incubated on rotation shaker until reaching the sufficient density for the induction $\left(\right.$ O.D. $\left.{ }_{600}=0.6\right)$. Expression of the recombinant asporin was induced by Isopropyl- $\beta$-D-thiogalacto-pyranoside (IPTG, final concentration $1 \mathrm{mM}$ ). Bacteria were incubated for another 5 hours and then harvested by the centrifugation. Bacterial pellet was resuspended in denaturating lysis buffer ( $8 \mathrm{M}$ urea buffered by $50 \mathrm{mM}$ Tris, $\mathrm{pH} 8$ ), sonicated $(10 x 10 \mathrm{~s}, 2 \mathrm{~min}$ intervals) and centrifugated $(10000 \mathrm{~g}, 10$ min, room temperature). The obtained supernatant was used for protein purification using the metaloaffinity chromatografy with Ni-NTA agarose. Washing and elution was performed using buffers with decreasing $\mathrm{pH}$ (8 M urea, $\mathrm{pH} 6.3 ; 5.9$ and 4.5). Glutathion-S-transferase recombinant asporin (H00054829-P01, Abnova, Taiwan) was purchased for quantification of asporin by mass spectrometry (Supplementary Figure S3).

\section{RNA isolation, reverse transcription and quantitative PCR}

Total RNA isolation was performed by the RNeasy Mini Kit (Qiagen), quantified by Nanodrop, pretreated with Dnase I (Invitrogen, Carlsbad, CA, USA) and reverse transcribed with random hexamers and SuperScript III Reverse Transcriptase (Invitrogen). The real-time polymerase chain reaction reactions were performed using specific primers and probes (ASPN forward 5'GGG TGA CGG TGT TCC ATA TC 3', reverse 5'TTG GTG GTA AGC CTT TAG GAA 3', probe 5' BHQ1-TTG CAG AAG CAA AAC TGA CC-FAM 3'; TBP forward 5'CAC GAA CCA CGG CAC TGA TT 3', reverse 5'TTT TCT TGC TGC CAG TCT GGA C 3', probe 5' BHQ1-TCT TCA CTC TTG GCT CCT GTG CAC A-HEX 3') and Probes Master Mix for 50 cycles of denaturation, annealing and extension $\left(95-60-72^{\circ} \mathrm{C}\right.$ each for $\left.20 \mathrm{~s}\right)$ at the LightCycler 480 instrument (Roche). Relative quantification was carried out according to the $\Delta \Delta \mathrm{Ct}$ method using TBP as a reference gene [57].

\section{Protein extraction and western blot analysis}

Cells were harvested into RIPA buffer $(50 \mathrm{mM}$ Tris $\mathrm{HCl} \mathrm{pH} 8.0 ; 150 \mathrm{mM} \mathrm{NaCl} ; 1 \% \mathrm{NP}-40 \quad 0.5 \%$ sodium deoxycholate; $0.1 \%$ SDS) supplemented with protease/phosphatase inhibitor cocktail (Roche). Twenty micrograms of whole cell lysate were separated by electrophoresis in $10 \%$ Bis-Tris polyacrylamide gel followed by blotting to nitrocellulose membrane. Nonspecific binding sites were blocked by incubating the blots for $2 \mathrm{hrs}$ at room temperature with $5 \%(\mathrm{w} / \mathrm{v})$ non-fat dry milk in PBS. Blots were incubated overnight with primary antibodies at the following concentrations: anti-ASPN (1:1000; \# HPA008435; Sigma-Aldrich, Protein Atlas; plus other antibodies specified in Supplementary Table S2), anti-FAK pY397 (1:500, Life Technologies), and antiGAPDH (1:25000; Sigma-Aldrich) was used as a loading control. Secondary antibodies were as follows anti-rabbit IgG, HRP-linked Antibody (\#7074) and Anti-mouse IgG, HRP-linked Antibody (\#7076), both purchased from Cell Signaling Technology, MA, USA. Signal detection was performed with Dura/ Femto ECL western blotting substrate (ThermoFisher Scientific). Analysis of optical density was performed using ImageJ software.

\section{In silico data mining}

Expression of asporin in cancer cell lines was checked either in Gene Expression Omnibus database at the National Center for Biotechnology Information or in ArrayExpress database at the European Bioinformatics Institute. The prognostic and predictive value of asporin (ASPN; 219087_at) was further evaluated by KaplanMeier Plotter (KMPLOT) [58], where all settings were left at default values (database version 2014; breast cancer analysis was performed from $8^{\text {th }}$ to $10^{\text {th }}$ September 2015; other cancer types were analysed on $23^{\text {rd }}$ February 2016).

\section{Genotyping of the asporin D-repeat polymorphism}

The aspartic acid (D) - repeat polymorphism located in the N-terminal region of the ASPN gene was evaluated according to Hurley et al. [32]. Briefly, PCR products (fluorescent forward primer 5' 6-FAM-ATT CCT GGC TTT GTG CTC TG and non-labeled reverse primer 5' TGG CTT CTT GGC TCT CTT GT) were mixed with GeneScan $^{\text {TM }} 500$ TAMRA $^{\text {TM }}$ Size Standard and Hi-DiTM Formamide (Applied Biosystems, Foster City, CA, USA) and denatured $3 \mathrm{~min}$ at $95^{\circ} \mathrm{C}$. Then, it was separated on ABI PRISM ${ }^{\circledR} 3130$ Genetic Analyzer and obtained data were analysed and visualised using GeneScan ${ }^{\circledR}$ Analysis Software (Applied Biosystems). Genotypes of BCAF3, 4 and 5 were D13/D14, D13/D14 and D13/D15, respectively.

Genotype of three samples (BCAF4, Hs578T and plasmid DNA from E.coli producing recombinant asporin; Supplementary Figure S6) was confirmed by Sanger sequencing. PCR was performed with the same primers (without FAM tag in the forward primer) using HotStarTaq Master Mix (Quiagen, Hilden, Germany). Products were purified by QIAquick PCR Purification kit (Qiagen) and used as a template for sequencing PCR which was performed using BigDye Terminator 
v1.1 Cycle Sequencing kit (Applied Biosystems). PCR products of this second PCR were purified by BigDye XTerminator ${ }^{\mathrm{TM}}$ Purification Kit (Applied Biosystems) and then separated by capillary electrophoresis on ABI PRISM $^{\circledR} 3100$ Genetic Analyzer (Applied Biosystems). Obtained data were analysed using Sequencing Analysis Software ${ }^{\mathrm{TM}}$ and visualised with GeneMapper ${ }^{\circledR}$ Software (Applied Biosystems). Whole procedure was performed according to the manufacturer protocol.

\section{ACKNOWLEDGMENTS}

We especially thank to Prof. Åke Oldberg for providing anti-aspn antibody, recombinant asporin and Rosetta-gami cells with expression vector. We are grateful also to Lucia Knopfova, Eva Slabakova and Viktor Horvath for their help with the invasion assays, Dusan Holub for comments on current mass spectrometry analyses and Prof. Paola Chiarugi for providing CAFs isolation protocol. Our thanks go also to Jana Holinkova, Eva Pimrova, Iva Liskova, Martina Urbankova and Katerina Svobodova for superb technical assistance.

\section{CONFLICTS OF INTEREST}

The authors have no conflicts of interest to declare.

\section{GRANT SUPPORT}

This work was supported in part by grants NV1631997A and NV15-33999A from the Czech Ministry of Health, TE02000058 from the Czech Technology Agency, CZ.1.05/3.1.00/14.0307, CZ.1.07/2.3.00/30.0022, RVO: 61989592, CZ09/7F14009 and NPS I LO1304 from the Czech Ministry of Education. MK, DS and TO were also supported by Palacky University (LF_2016_011, 013 and 019, respectively), TS by Charles University (GA UK No. 304313), KS and ZK by project no. LQ1605 from the National Program of Sustainability II (MEYS CR), by the project FNUSA-ICRC no. CZ.1.05/1.1.00/02.0123 (OP $\mathrm{VaVpI}$ ) and by European Union - project ICRC-ERAHumanBridge (No. 316345).

\section{REFERENCES}

1. Kharaishvili G, Simkova D, Bouchalova K, Gachechiladze M, Narsia N, Bouchal J. The role of cancer-associated fibroblasts, solid stress and other microenvironmental factors in tumor progression and therapy resistance. Cancer Cell Int. 2014; 14: 41. doi: 10.1186/1475-2867-14-41.

2. Bosman FT, Stamenkovic I. Functional structure and composition of the extracellular matrix. J Pathol. 2003; 200: 423-8. doi: 10.1002/path.1437.

3. Jean C, Gravelle P, Fournie JJ, Laurent G. Influence of stress on extracellular matrix and integrin biology. Oncogene. 2011; 30: 2697-706. doi: 10.1038/onc.2011.27.
4. Mecham RP. Overview of extracellular matrix. Curr Protoc Cell Biol. 2001; Chapter 10: Unit 10.1. doi: 10.1002/0471143030.cb1001s00.

5. Schaefer L, Iozzo RV. Biological functions of the small leucine-rich proteoglycans: from genetics to signal transduction. J Biol Chem. 2008; 283: 21305-9. doi: 10.1074/jbc.R800020200.

6. Henry SP, Takanosu M, Boyd TC, Mayne PM, Eberspaecher H, Zhou W, de Crombrugghe B, Hook M, Mayne R. Expression pattern and gene characterization of asporin. a newly discovered member of the leucine-rich repeat protein family. J Biol Chem. 2001; 276: 12212-21. doi: 10.1074/ jbc.M011290200.

7. Lorenzo P, Aspberg A, Onnerfjord P, Bayliss MT, Neame PJ, Heinegard D. Identification and characterization of asporin. a novel member of the leucine-rich repeat protein family closely related to decorin and biglycan. J Biol Chem. 2001; 276: 12201-11. doi: 10.1074/jbc.M010932200.

8. Yamada S, Murakami S, Matoba R, Ozawa Y, Yokokoji T, Nakahira Y, Ikezawa K, Takayama S, Matsubara K, Okada $H$. Expression profile of active genes in human periodontal ligament and isolation of PLAP-1, a novel SLRP family gene. Gene. 2001; 275: 279-86.

9. Kou I, Nakajima M, Ikegawa S. Binding characteristics of the osteoarthritis-associated protein asporin. J Bone Miner Metab. 2010; 28: 395-402. doi: 10.1007/ s00774-009-0145-8.

10. Kalamajski S, Aspberg A, Lindblom K, Heinegård D, Oldberg A. Asporin competes with decorin for collagen binding, binds calcium and promotes osteoblast collagen mineralization. Biochem J. 2009; 423: 53-9. doi: 10.1042/ BJ20090542.

11. Ikegawa $\mathrm{S}$. The genetics of common degenerative skeletal disorders: osteoarthritis and degenerative disc disease. Annu Rev Genomics Hum Genet. 2013; 14: 245-56. doi: 10.1146/ annurev-genom-091212-153427.

12. Turashvili G, Bouchal J, Baumforth K, Wei W, Dziechciarkova M, Ehrmann J, Klein J, Fridman E, Skarda J, Srovnal J, Hajduch M, Murray P, Kolar Z. Novel markers for differentiation of lobular and ductal invasive breast carcinomas by laser microdissection and microarray analysis. BMC Cancer. 2007; 7: 55. doi: 10.1186/1471-2407-7-55.

13. Kharaishvili G, Cizkova M, Bouchalova K, Mgebrishvili G, Kolar Z, Bouchal J. Collagen triple helix repeat containing 1 protein, periostin and versican in primary and metastatic breast cancer: an immunohistochemical study. J Clin Pathol. 2011; 64: 977-82. doi: 10.1136/jclinpath-2011-200106.

14. Malanchi I, Santamaria-Martínez A, Susanto E, Peng H, Lehr HA, Delaloye JF, Huelsken J. Interactions between cancer stem cells and their niche govern metastatic colonization. Nature. 2012; 481: 85-9. doi: 10.1038/ nature 10694.

15. Ma XJ, Wang Z, Ryan PD, Isakoff SJ, Barmettler A, Fuller A, Muir B, Mohapatra G, Salunga R, Tuggle JT, Tran Y, 
Tran D, Tassin A, et al. A two-gene expression ratio predicts clinical outcome in breast cancer patients treated with tamoxifen. Cancer Cell. 2004; 5: 607-16. doi: 10.1016/j. ccr.2004.05.015.

16. Best CJ, Gillespie JW, Yi Y, Chandramouli GV, Perlmutter MA, Gathright Y, Erickson HS, Georgevich L, Tangrea MA, Duray PH, González S, Velasco A, Linehan WM, et al. Molecular alterations in primary prostate cancer after androgen ablation therapy. Clin Cancer Res. 2005; 11: 6823-34. doi: 10.1158/1078-0432.CCR-05-0585.

17. Stanbrough M, Bubley GJ, Ross K, Golub TR, Rubin MA, Penning TM, Febbo PG, Balk SP. Increased expression of genes converting adrenal androgens to testosterone in androgen-independent prostate cancer. Cancer Res. 2006; 66: 2815-25. doi: 10.1158/0008-5472.CAN-05-4000.

18. Mackay A, Urruticoechea A, Dixon JM, Dexter T, Fenwick K, Ashworth A, Drury S, Larionov A, Young O, White S, Miller WR, Evans DB, Dowsett M. Molecular response to aromatase inhibitor treatment in primary breast cancer. Breast Cancer Res. 2007; 9: R37. doi: 10.1186/bcr1732.

19. Rajkumar T, Vijayalakshmi N, Gopal G, Sabitha K, Shirley S, Raja UM, Ramakrishnan SA. Identification and validation of genes involved in gastric tumorigenesis. Cancer Cell Int. 2010; 10: 45. doi: 10.1186/1475-2867-10-45.

20. Cima I, Schiess R, Wild P, Kaelin M, Schüffler P, Lange V, Picotti P, Ossola R, Templeton A, Schubert O, Fuchs $\mathrm{T}$, Leippold $\mathrm{T}$, Wyler $\mathrm{S}$, et al. Cancer genetics-guided discovery of serum biomarker signatures for diagnosis and prognosis of prostate cancer. Proc Natl Acad Sci U S A. 2011; 108: 3342-7. doi: 10.1073/pnas.1013699108.

21. Turtoi A, Musmeci D, Wang Y, Dumont B, Somja J, Bevilacqua G, De Pauw E, Delvenne P, Castronovo V. Identification of novel accessible proteins bearing diagnostic and therapeutic potential in human pancreatic ductal adenocarcinoma. J Proteome Res. 2011; 10: 430213. doi: $10.1021 / \mathrm{pr} 200527 \mathrm{z}$.

22. Klee EW, Bondar OP, Goodmanson MK, Dyer RB, Erdogan S, Bergstralh EJ, Bergen HR, Sebo TJ, Klee GG. Candidate serum biomarkers for prostate adenocarcinoma identified by mRNA differences in prostate tissue and verified with protein measurements in tissue and blood. Clin Chem. 2012; 58: 599-609. doi: 10.1373/clinchem.2011.171637.

23. Orr B, Riddick AC, Stewart GD, Anderson RA, Franco OE, Hayward SW, Thomson AA. Identification of stromally expressed molecules in the prostate by tag-profiling of cancer-associated fibroblasts, normal fibroblasts and fetal prostate. Oncogene. 2012; 31: 1130-42. doi: 10.1038/ onc.2011.312.

24. Satoyoshi R, Kuriyama S, Aiba N, Yashiro M, Tanaka M. Asporin activates coordinated invasion of scirrhous gastric cancer and cancer-associated fibroblasts. Oncogene 2014; 34: 650-60. doi: 10.1038/onc.2013.584.

25. Maris P, Blomme A, Palacios AP, Costanza B, Bellahcène A, Bianchi E, Gofflot S, Drion P, Trombino GE, Di Valentin
E, Cusumano PG, Maweja S, Jerusalem G, et al. Asporin Is a Fibroblast-Derived TGF- $\beta 1$ Inhibitor and a Tumor Suppressor Associated with Good Prognosis in Breast Cancer. PLoS Med. 2015; 12: e1001871. doi: 10.1371/ journal.pmed.1001871.

26. Lee EH, Park HJ, Jeong JH, Kim YJ, Cha DW, Kwon DK, Lee $\mathrm{SH}$, Cho JY. The role of asporin in mineralization of human dental pulp stem cells J Cell Physiol. 2011; 226: 1676-82. doi: 10.1002/jcp.22498.

27. Kou I, Nakajima M, Ikegawa S. Expression and regulation of the osteoarthritis-associated protein asporin. J Biol Chem. 2007; 282: 32193-9. doi: 10.1074/jbc.M706262200.

28. Duval E, Bigot N, Hervieu M, Kou I, Leclercq S, Galéra $\mathrm{P}$, Boumediene $\mathrm{K}$, Baugé C. Asporin expression is highly regulated in human chondrocytes. Mol Med. 2011; 17: 81623. doi: 10.2119/molmed.2011.00052.

29. Yamada S, Ozawa Y, Tomoeda M, Matoba R, Matsubara $\mathrm{K}$, Murakami S. Regulation of PLAP-1 expression in periodontal ligament cells. J Dent Res. 2006; 85: 447-51.

30. Sodek KL, Brown TJ, Ringuette MJ. Collagen I but not Matrigel matrices provide an MMP-dependent barrier to ovarian cancer cell penetration. BMC Cancer. 2008; 8: 223. doi: 10.1186/1471-2407-8-223.

31. Prat A, Karginova O, Parker JS, Fan C, He X, Bixby L, Harrell JC, Roman E, Adamo B, Troester M, Perou CM. Characterization of cell lines derived from breast cancers and normal mammary tissues for the study of the intrinsic molecular subtypes. Breast Cancer Res Treat. 2013; 142: 237-55. doi: 10.1007/s10549-013-2743-3.

32. Hurley PJ, Sundi D, Shinder B, Simons BW, Hughes RM, Miller RM, Benzon B, Faraj SF, Netto GJ, Vergara IA, Erho N, Davicioni E, Karnes RJ, et al. Germline Variants in Asporin Vary by Race, Modulate the Tumor Microenvironment, and Are Differentially Associated with Metastatic Prostate Cancer. Clin Cancer Res. 2016; 22: 44858. doi: 10.1158/1078-0432.CCR-15-0256.

33. Correia AL, Bissell MJ. The tumor microenvironment is a dominant force in multidrug resistance. Drug Resist Updat. 2012; 15: 39-49. doi: 10.1016/j.drup.2012.01.006.

34. Rajan N, Elliott R, Clewes O, Mackay A, Reis-Filho JS, Burn J, Langtry J, Sieber-Blum M, Lord CJ, Ashworth A. Dysregulated TRK signalling is a therapeutic target in CYLD defective tumours. Oncogene. 2011; 30: 4243-60. doi: 10.1038/onc.2011.133.

35. Stylianopoulos T, Martin JD, Chauhan VP, Jain SR, DiopFrimpong B, Bardeesy N, Smith BL, Ferrone CR, Hornicek FJ, Boucher Y, Munn LL, Jain RK. Causes, consequences, and remedies for growth-induced solid stress in murine and human tumors. Proc Natl Acad Sci U S A. 2012; 109: 15101-8. doi: 10.1073/pnas.1213353109.

36. Kretschmer C, Sterner-Kock A, Siedentopf F, Schoenegg W, Schlag PM, Kemmner W. Identification of early molecular markers for breast cancer. Mol Cancer. 2011; 10: 15. doi: 10.1186/1476-4598-10-15. 
37. Gao H, Chakraborty G, Lee-Lim AP, Mo Q, Decker M, Vonica A, Shen R, Brogi E, Brivanlou AH, Giancotti FG. The BMP inhibitor Coco reactivates breast cancer cells at lung metastatic sites. Cell. 2012; 150: 764-79. doi: 10.1016/j.cell.2012.06.035.

38. Wan L, Pantel K, Kang Y. Tumor metastasis: moving new biological insights into the clinic. Nat Med. 2013; 19: 145064. doi: 10.1038/nm.3391.

39. Levin VA, Panchabhai SC, Shen L, Kornblau SM, Qiu Y, Baggerly KA. Different changes in protein and phosphoprotein levels result from serum starvation of highgrade glioma and adenocarcinoma cell lines. J Proteome Res. 2010; 9: 179-91. doi: 10.1021/pr900392b.

40. Lee AS. Glucose-regulated proteins in cancer: molecular mechanisms and therapeutic potential. Nat Rev Cancer. 2014; 14: 263-76. doi: 10.1038/nrc3701.

41. Leccia F, Nardone A, Corvigno S, Vecchio LD, De Placido $\mathrm{S}$, Salvatore F, Veneziani BM. Cytometric and biochemical characterization of human breast cancer cells reveals heterogeneous myoepithelial phenotypes. Cytometry A. 2012; 81: 960-72. doi: 10.1002/cyto.a.22095.

42. Ding Q, Zhang M, Liu C. Asporin participates in gastric cancer cell growth and migration by influencing EGF receptor signaling. Oncol Rep. 2015; 33: 1783-90. doi: 10.3892/or.2015.3791

43. Wolf DM, Lenburg ME, Yau C, Boudreau A, van 't Veer LJ. Gene co-expression modules as clinically relevant hallmarks of breast cancer diversity. PLoS One. 2014; 9: e88309. doi: 10.1371/journal.pone.0088309.

44. Klein A, Olendrowitz C, Schmutzler R, Hampl J, Schlag PM, Maass N, Arnold N, Wessel R, Ramser J, Meindl A, Scherneck S, Seitz S. Identification of brain- and bonespecific breast cancer metastasis genes. Cancer Lett 2009; 276: 212-20. doi: 10.1016/j.canlet.2008.11.017.

45. Dangaria SJ, Ito Y, Luan X, Diekwisch TG. Differentiation of neural-crest-derived intermediate pluripotent progenitors into committed periodontal populations involves unique molecular signature changes, cohort shifts, and epigenetic modifications. Stem Cells Dev. 2011; 20: 39-52. doi: 10.1089/scd.2010.0180.

46. Kizawa H, Kou I, Iida A, Sudo A, Miyamoto Y, Fukuda A, Mabuchi A, Kotani A, Kawakami A, Yamamoto S, Uchida A, Nakamura K, Notoya K, et al. An aspartic acid repeat polymorphism in asporin inhibits chondrogenesis and increases susceptibility to osteoarthritis. Nat Genet. 2005; 37: 138-44. doi: 10.1038/ng1496.

47. Giannoni E, Bianchini F, Masieri L, Serni S, Torre E, Calorini L, Chiarugi P. Reciprocal activation of prostate cancer cells and cancer-associated fibroblasts stimulates epithelial-mesenchymal transition and cancer stemness. Cancer Res. 2010; 70: 6945-56. doi: 10.1158/0008-5472.

48. Giannoni E, Bianchini F, Calorini L, Chiarugi P. Cancer associated fibroblasts exploit reactive oxygen species through a proinflammatory signature leading to epithelial mesenchymal transition and stemness. Antioxid Redox Signal. 2011; 14: 2361-71. doi: 10.1089/ars.2010.3727.

49. Mokry J, Soukup T, Micuda S, Karbanova J, Visek B, Brcakova E, Suchanek J, Bouchal J, Vokurkova D, Ivancakova $\mathrm{R}$. Telomere attrition occurs during ex vivo expansion of human dental pulp stem cells. J Biomed Biotechnol. 2010; 2010: 673513. doi: 10.1155/2010/673513.

50. Levental KR, Yu H, Kass L, Lakins JN, Egeblad M, Erler JT, Fong SF, Csiszar K, Giaccia A, Weninger W, Yamauchi M, Gasser DL, Weaver VM. Matrix crosslinking forces tumor progression by enhancing integrin signaling. Cell. 2009; 139: 891-906. doi: 10.1016/j.cell.2009.10.027.

51. Friedrich J, Seidel C, Ebner R, Kunz-Schughart LA. Spheroid-based drug screen: considerations and practical approach. Nat Protoc. 2009; 4: 309-24. doi: 10.1038/ nprot.2008.226.

52. Li Q, Chen C, Kapadia A, Zhou Q, Harper MK, Schaack J, LaBarbera DV. 3D models of epithelial-mesenchymal transition in breast cancer metastasis: high-throughput screening assay development, validation, and pilot screen. J Biomol Screen. 2011; 16: 141-54. doi: 10.1177/1087057110392995.

53. Andersson AC, Strömberg S, Bäckvall H, Kampf C, Uhlen M, Wester K, Pontén F. Analysis of protein expression in cell microarrays: a tool for antibody-based proteomics. J Histochem Cytochem. 2006; 54: 1413-23. doi: 10.1369/ jhc.6A7001.2006.

54. Wang F, Flanagan J, Su N, Wang LC, Bui S, Nielson A, Wu X, Vo HT, Ma XJ, Luo Y. RNAscope: a novel in situ RNA analysis platform for formalin-fixed, paraffin-embedded tissues. J Mol Diagn. 2012; 14: 22-9. doi: 10.1016/j. jmoldx.2011.08.002.

55. Dreyer JH, Hauck F, Oliveira-Silva M, Barros $\mathrm{MH}$, Niedobitek G. Detection of HPV infection in head and neck squamous cell carcinoma: a practical proposal. Virchows Arch. 2013; 462: 381-9. doi: 10.1007/s00428-013-1393-5.

56. MacLean B, Tomazela DM, Shulman N, Chambers M, Finney GL, Frewen B, Kern R, Tabb DL, Liebler DC, MacCoss MJ. Skyline: an open source document editor for creating and analyzing targeted proteomics experiments. Bioinformatics. 2010; 26: 966-8. doi: 10.1093/ bioinformatics/btq054.

57. Pfaffl MW. A new mathematical model for relative quantification in real-time RT-PCR. Nucleic Acids Res. 2001; 29: e45. doi: 10.1093/nar/29.9.e45

58. Györffy B, Lanczky A, Eklund AC, Denkert C, Budczies J, Li Q, Szallasi Z. An online survival analysis tool to rapidly assess the effect of 22,277 genes on breast cancer prognosis using microarray data of 1,809 patients. Breast Cancer Res Treat. 2010; 123: 725-31. doi: 10.1007/s10549-009-0674-9. 